\title{
Experimental Design for Evaluation of Formation Damage by Microbial Contamination in Water Flooding Processes. A Colombian Study Case
}

\author{
Ecopetrol S.A. \\ Código Postal: 681011. Piedecuesta - Colombia \\ Email: "manuel.jaimes@ecopetrol.com.co \\ ${ }^{* *}$ martin.escobar@ecopetrol.com.co \\ ****rodrigo.torres@ecopetrol.com.co
}

Manuel Guillermo Jaimes Plata*, Martin Augusto Escobar Hernández**, Rodrigo Gonzalo Torres Sáez

\begin{abstract}
Microbial contamination is well known in the oil and gas industry and it occurs in most processes where water processing systems are involved. Microorganisms are spread everywhere, even in the subsurface, where operations of oil exploration and production are developed. For this reason, different genera of microorganisms can affect the Oil \& Gas Industry. One of the major problems in oil mature fields undergoing secondary recovery is the contamination with sulfate reducing bacteria (SRB), caused generally by the injection water system (fresh and/or production) and/or of the reservoir (natural or by drilling fluids, completion, stimulation, etc.). This problem causes formation damage and microbiological induced corrosion (MIC) in the injection-production system. In many producing wells, formation damage by microbiological contamination is initially masked by a decline in reservoir pressure; however, initial production of $\mathrm{H}_{2} \mathrm{~S}$ does provide a possible microbial contamination of water production, water injection and eventually petroleum reservoir. In some producing wells, $\mathrm{H}_{2} \mathrm{~S}$ concentrations have exceeded the lethal limits of $250 \mathrm{ppm}$ and there are cases of producing wells with levels above $1000 \mathrm{ppm}$. In this work, both a conceptual study and an experimental protocol were developed for the evaluation of formation damage by microbial contamination in water flooding processes. It is focused on finding the best stimulation treatment with biocides to $\mathrm{H}_{2} \mathrm{~S}$ and corrosion control in Producer Wells of Oil Fields Undergoing Secondary Recovery as part of the comprehensive strategy to implement in the injection-reservoir-production system of the Chichimene field in Colombia. This study included the following stages:

1. State of the art to define main bactericides, matrix stimulation treatments to $\mathrm{H}_{2} \mathrm{~S}$ and corrosion control, removal of biomass (biofilm) and iron sulfide, etc. in producers wells.

2. Conceptual study of the formation damage by growth of sulfate-reducing bacteria.

3. Experimental protocol for the evaluation of formation damage due to microbial contamination in water flood processes.

4. Experimental evaluation of formation damage due to microbial contamination in cores of the Chichimene field, in Colombia.
\end{abstract}

Finally, the main findings, conclusions and recommendations obtained in this study are shown.

Keywords: microbial contamination, microorganisms, secondary recovery, stimulation, formation damage, sulfate-reducing bacteria, water production, waterflooding.

\section{Diseño experimental para la evaluación del daño de formación por contaminación microbiana en procesos de inundación de agua. Un caso de estudio colombiano}

\section{Resumen}

La contaminación microbiana es bien conocida en la industria del petróleo y el gas y se produce en la mayoría de los procesos donde están involucrados sistemas de procesamiento de agua. Los microorganismos se propagan en todas partes, incluso en el subsuelo, donde se desarrollan las operaciones de exploración y producción de petróleo, por esta razón, diferentes géneros de microorganismos pueden afectar a la industria de petróleo y gas. Uno de los principales problemas en los campos maduros de petróleo que experimentan una recuperación secundaria es la contaminación con bacterias reductoras de sulfato (SRB) causada

Cita: Jaimes Plata, M. G., Escobar Hernández, M. A. \& Torres Sáez, R. G. (2019). Experimental Design for Evaluation of Formation Damage by Microbial Contamination in Water Flooding Processes. A Colombian Study Case. Revista Fuentes: El reventón energético, vol 17(2), 7-17. 
generalmente por el sistema de inyección de agua (fresco y / o producción) y / o del reservorio (natural o por fluidos de perforación, finalización, estimulación, etc.). Este problema causa daños en la formación y corrosión microbiológica inducida (MIC) en el sistema de inyección-producción. En muchos pozos productores, el daño de la formación por contaminación microbiológica está inicialmente oculto por una disminución en la presión del yacimiento; sin embargo, la producción inicial de $\mathrm{H}_{2} \mathrm{~S}_{\text {proporciona una }}$ posible contaminación microbiana de la producción de agua, la inyección de agua y, eventualmente, el reservorio de petróleo. En algunos pozos productores, las concentraciones de $\mathrm{H}_{2} \mathrm{~S}$ han excedido los límites letales de 250 ppm y hay casos de pozos productores con niveles superiores a $1000 \mathrm{ppm}$. En este trabajo, se desarrollaron tanto un estudio conceptual como un protocolo experimental para evaluar el daño de la formación por contaminación microbiana en los procesos de inundación de agua, enfocado en encontrar el mejor tratamiento de estimulación con biocidas para el H2S y el control de la corrosión en los pozos productores de campos petroleros en recuperación secundaria como parte de la estrategia integral para implementar en el sistema de producción de inyección y reservorio del campo Chichimene en Colombia. Este estudio incluyó las siguientes etapas:

1. Estado del arte para definir los principales bactericidas, los tratamientos de estimulación de la matriz para el $\mathrm{H}_{2} \mathrm{~S}$ y el control de la corrosión, la eliminación de biomasa (biofilm) y sulfuro de hierro, etc., en los pozos productores.

2. Estudio conceptual del daño de la formación por el crecimiento de bacterias reductoras de sulfato.

3. Protocolo experimental para la evaluación de daños de formación por contaminación microbiana en procesos de inundación de agua.

4. Evaluación experimental del daño de la formación por contaminación microbiana en los núcleos del campo Chichimene, en Colombia.

Finalmente, se muestran los principales hallazgos, conclusiones y recomendaciones obtenidas en este estudio.

Palabras clave: contaminación microbiana, microorganismos, recuperación secundaria, estimulación, daño a la formación, bacterias reductoras de sulfato, producción de agua, inyección de agua.

\section{Introduction}

Microbes are the most abundant life forms throughout the planet. It was the first link in the evolutionary chain and they are an essential part of the terrestrial biota. Microbes catalyzing major changes in the biosphere produce key components of the atmosphere and represent a large part of the genetic diversity of the planet. The number of microbial cells in the soil has been estimated 4 to $6 \times 10^{30}$ cells and this accumulated mass contains from 350 to $550 \times 10^{15}$ grams of carbon (Whitman, et al., 1988). For years, it was thought that the temperature, pressure and salinity in most field were too hostile for microbes to thrive. However, with the start of production of oil and gas in the North Sea in the 1960s it was demonstrated that the initial assumptions were not correct. Microbes in these oil fields not only are able to live at extreme conditions, but also produced hydrogen sulfide $\left[\mathrm{H}_{2} \mathrm{~S}\right]$ and clogged with biomass the formations, during injection of water (Oilfield Review, 2012).

Hydrogen sulfide $\left(\mathrm{H}_{2} \mathrm{~S}\right)$ production is one of the most critical problems in both primary recovery and secondary recovery of oil and gas. This compound is a gas caused by one or more of the following reasons: first, sulfate-reducing bacterial contamination (SRB) or fresh water production, which is then used as injection water; secondly, sulfate-reducing bacteria naturally occurring in the reservoir, and thirdly, use of contaminated water during the drilling completion and stimulation operations, etc. (Velandia, 2013). The SRB can reduce sulfate ions $\left(\mathrm{SO}_{4}^{2-}\right)$ to sulfide $\left(\mathrm{S}^{2-}\right)$, with the consequent production of hydrogen sulfide $\left(\mathrm{H}_{2} \mathrm{~S}\right)$. Another compound is produced when the sulfide ion combines with $\mathrm{Fe}^{2+}$ (resulting mainly from corrosion phenomena on facilities) to form solid iron sulfide (FeS), increasing the load of suspended solids in water injection, with the consequent formation damage (Maya, et al., 2018).

Another reason that motivates the treatment of $\mathrm{H}_{2} \mathrm{~S}$ is the environmental regulations for emissions of sulfur compounds. When the $\mathrm{H}_{2} \mathrm{~S}$ is burned, it oxidizes and forms sulfur dioxide $\left(\mathrm{SO}_{2}\right)$ which is released in gaseous form and interacts with the water vapor in the atmosphere as acid rain.

In Colombia, there are seven crude oil basins (See Figure 1): Caguán-Putumayo, Catatumbo, Eastern Mountain chain, Eastern Llanos, Lower, Middle and Upper Magdalena River Valley. In these basins, there are $33646 \mathrm{MMBO}$ of original oil in place, distributed in 280 oil fields currently producing 1,012 MBOPD with an average recovery factor of $19 \%$, equivalent to 6471 MMBO cumulative production, and with estimated ultimate reserves of 2,260 $\mathrm{MMBO}$, equivalent to an ultimate recovery factor of $23 \%$ (Martín, et al., 2017) (Galvis, et al., 2013) (Díaz, et al., 2007). Only 19 of the 280 fields have carried out water injection processes and none of them have developed tertiary recovery. The 
$80 \%$ comes from primary production and $20 \%$ from secondary production. Table 1 shows the areas under the respective secondary recovery volume of water injected per day (Jaimes, et al., 2014).

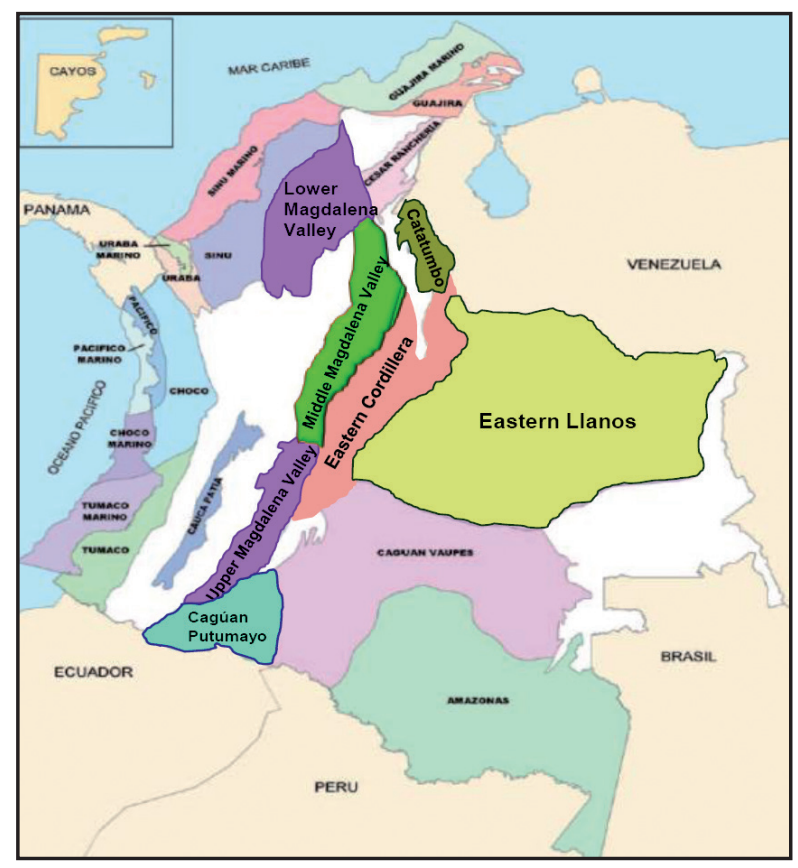

Figure 1. Colombian Hydrocarbon Basins.

Table 1. Volume of injected water in different oil fields

\begin{tabular}{|l|c|}
\hline \multicolumn{1}{|c|}{ Field } & Water Injection (barrels per day) \\
\hline Casabe & 119,692 \\
\hline Cira Infantas & 416,088 \\
\hline Yariguí-Cantagallo & 53,000 \\
\hline Tello & 58,000 \\
\hline Palogrande-Cebú & 20,000 \\
\hline Yaguará & 55,000 \\
\hline Rio Ceibas & 6,000 \\
\hline Dina & 33,000 \\
\hline Tenay & 3,600 \\
\hline Pijao & 1,000 \\
\hline Tibú & 31,600 \\
\hline San Francisco & 260,000 \\
\hline Balcón & 8,800 \\
\hline Guando & 100,000 \\
\hline Matachin Norte & 86,000 \\
\hline
\end{tabular}

The issues raised in the preceding paragraphs are presented in several fields in Colombia (Casabe, La Cira-Infantas, Mangos, Costayaco Chichimene, etc.) becoming more critical, not only for the decreasing in oil productivity, but mainly because of the risk of causing adverse effects on health of the people, as, in some wells, $\mathrm{H}_{2} \mathrm{~S}$ concentrations have exceeded lethal limits. In order to mitigate this problem, a comprehensive approach must be considered throughout the entire Injection-Reservoir-Production system. As a beginning of this strategy (Shock Plan), this study was focused in the evaluation of formation damage by microbial contamination in water flooding processes in the Chichimene field in Colombia.

\section{Field of study and characterization of the problem}

In Colombia, in the last years, the number of fields undergoing secondary recovery processes has been increasing. Fresh water and produced water are used. Inadequate microbiological control in these water sources as well as drilling fluids, completion, stimulation, etc., have allowed the proliferation of SRB throughout the entire injection-reservoir-production system, thereby increasing levels of $\mathrm{H}_{2} \mathrm{~S}$.

As mentioned above, this work was focused in the evaluation of formation damage by microbial contamination in water flooding processes, which serve to select and evaluate the optimal stimulation treatment to remove formation damage and control the production of $\mathrm{H}_{2} \mathrm{~S}$. As a field of study was selected the Chichimene field in Colombia.

In Figure 2 is shown a comparison of the population of SRB injection wells monitored in different fields in Colombia in 2012.

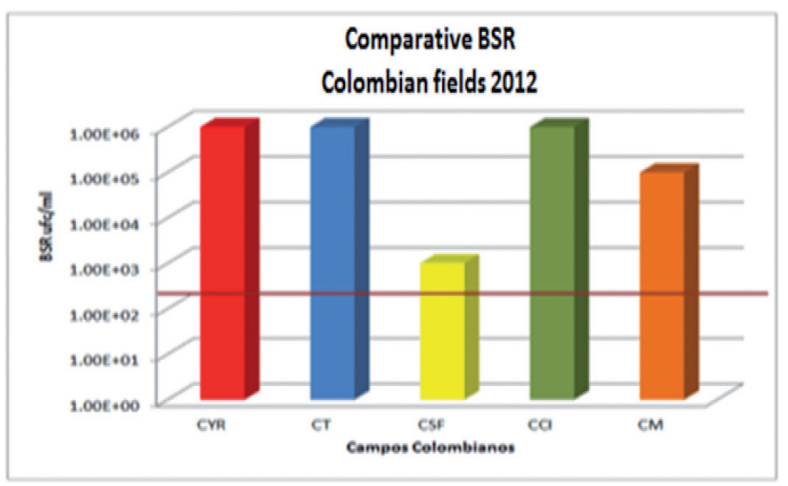

Figure 2. SRB concentration in Colombian oilfields, 2012.

\section{History and generalities of Chichimene Oil Field}

The Chichimene oil-field is sited to $30 \mathrm{Km}$ from south of Villavicencio at the Department of Meta-Colombia (See Figure 3). 


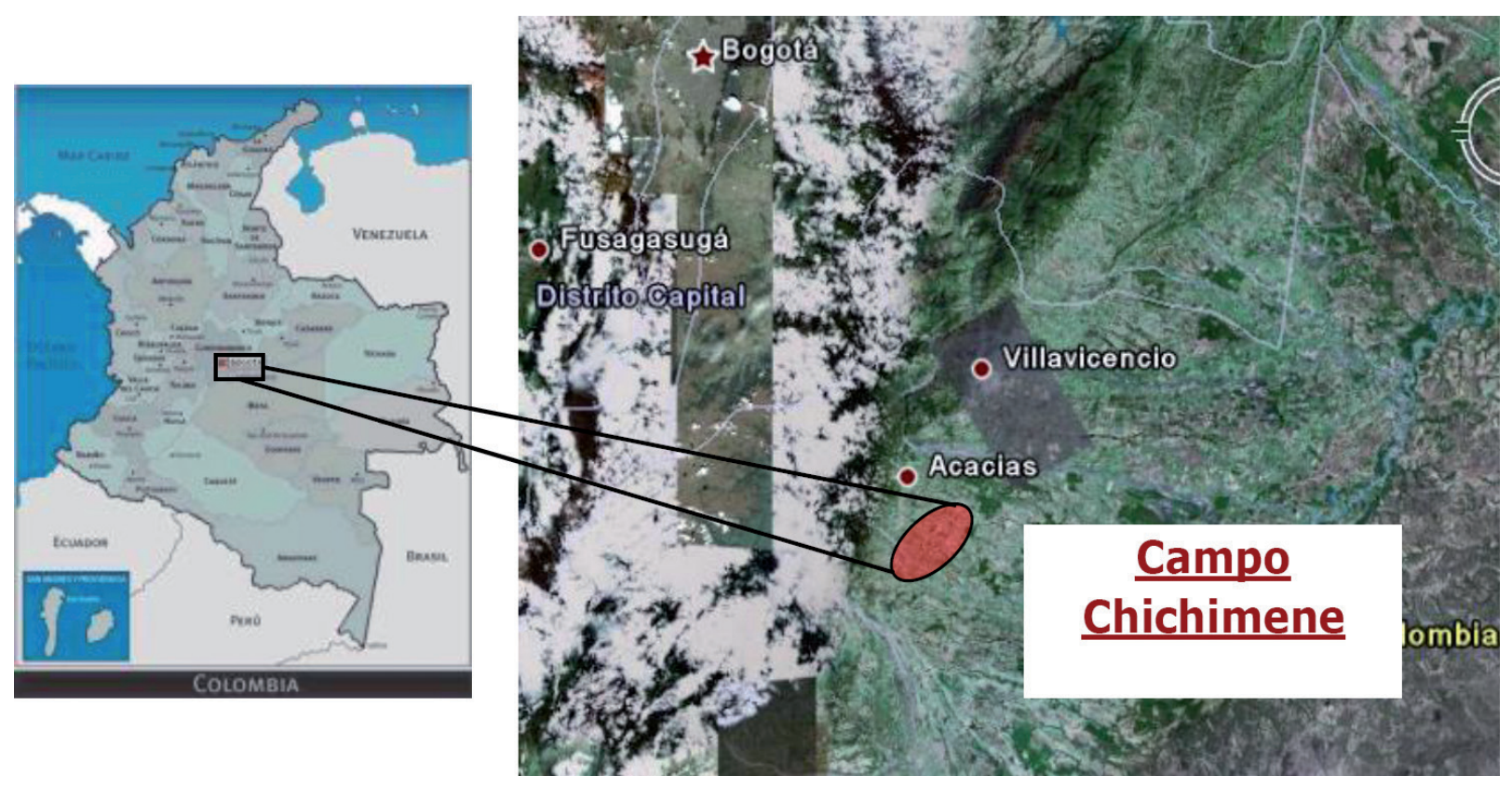

Figure 3. Geographical Site of Chichimene Oil Field

Chichimene Oil Field was discovered by Chevron in 1969 with drilling of Chichimene-1 oil well and started production in 1985. Currently, this oil field counts with 190 oil wells drilled at 2018. Producing crude oil of $20^{\circ} \mathrm{API}$ from $\mathrm{K} 1$ and $\mathrm{K} 2$ formation units, producing in one set of three producing units (K1, K2 and T2) with crude oil $15^{\circ} \mathrm{API}$ and producing crude oil of $8^{\circ}$ API from T2 unit. Mean production of this field until September/2018 was 70.000 BOPD with a water shutoff of $39.9 \%$.

Producer units are both massive and superior Guadalupe formations from Middle Cretaceous Period, corresponding to operational units $\mathrm{K} 2$ and K1. In Table $\mathbf{2}$ are displayed currant OOIP estimations.

Table 2. Estimations of OOIP.

\begin{tabular}{|c|c|c|}
\hline \multicolumn{1}{|c|}{ Year } & OOIP K1-K2 (MBLS) & OOIP T2 \\
\hline 2010 & 247 & 2577 \\
\hline 2009 & 247 & 2577 \\
\hline 2008 & 122 & 1303 \\
\hline 2007 & 122 & 846 \\
\hline
\end{tabular}

It is estimated that Chichimene oil field gets a cumulative production in $\mathrm{K} 1-\mathrm{K} 2$ units of $46.5 \mathrm{MB} 1 \mathrm{~s}$ on December 2012. This represents an oil recovery factor of $18.8 \%$ and a cumulative production in $\mathrm{T} 2$ unit of $38.7 \mathrm{MBLs}$, which represents an oil recovery factor of $1.5 \%$.

\section{Conceptual Study}

In the last decades, most of research about petroleum microorganisms in oil fields has been focused in short term strategies for mitigation of negative effects of microbial contamination. However, little studies have been performed in order to understand microbiological mechanisms of formation damage of oil reservoir. Moreover, there is a great interest in microbial diagnostic, control and mitigation, in order to avoid biocorrosion phenomena and reservoir contamination caused by biofilm formation (Wikieł, et al., 2014). Currently, several studies can be performed for microbial characterization using new methodologies, including metagenomics, molecular biology and bioinformatics tools, providing a system biology vision (Lomans, et al., 2016). On the other hand, new advances in chemical treatment of injection waters and new strategies such as biocompetence or use of bacteriophages, provide a safe environmentally control in order to avoid oil souring and biocorrosion (Summer, et al., 2014).

Bacterial Contamination. Our perception of bacteria as unicellular life forms can be attributed to the axenic ("pure") culture paradigm. While suspensions of bacteria growing in liquid medium have enabled the discovery of the main features of microbial physiology and genetics, in nature bacteria rarely grow as axenic cultures. Instead, they predominately exist as communities of sessile cells that develop as biofilms (Berlanga \& Guerrero, 2016). 
Bacteria and Biofilm. Bacteria are distributed in nature in two forms or states: a) planktonic bacteria, free-floating b) sessile bacteria, in colonies of microorganisms growing in environments called biofilms, attached to surfaces. The population of bacteria in a biofilm (sessile) may be more than 1,000,000 times the floating population in the aqueous medium surrounding the biofilm (planktonic). The planktonic bacteria become sessile when adhering to the surface. The examination of these biofilms has shown that the bacteria are embedded in an acid polysaccharide matrix called glycocalyx. It is because of this polysaccharide "protector" that bacterial colonies are isolated from bactericide attack. Even higher concentrations of bactericides do not guarantee the destruction of the resident population in the biofilm [12]. Biocides (or at least their usual dose) that control planktonic bacteria do not necessarily do the same to the sessile as well, mainly due to particular bacterial growth habitat of the latter. Figure 4 shows step by step the formation of a biofilm, since the adsorption of microorganisms, exopolymers formation and growth to form the biofilm.

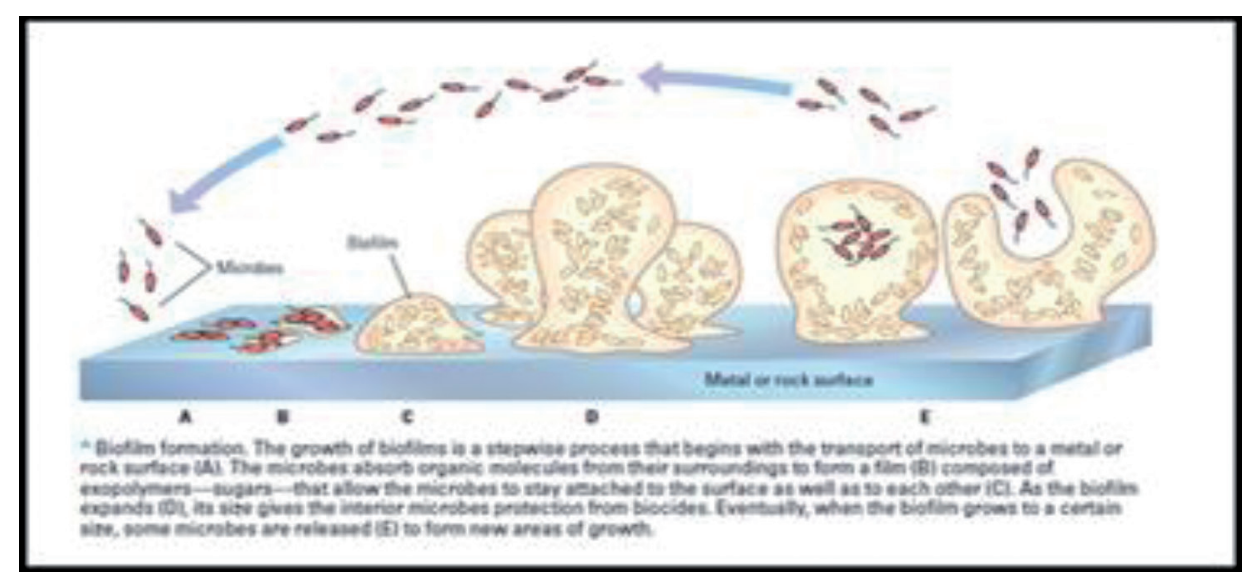

Figure 4. Biofilm formation on metal or rock surface

(Taken from Oilfield Review. Microbes Oilfield Enemies or Allies. Summer 2012.)

How the microorganisms enter to the production system. The bacteria may be present naturally in the wells or in the reservoir, or can enter through any source of water used for drilling fluids, completion, fracturing, stimulation, treatments, secondary recovery, etc.

Problems caused by bacteria. The main problems are: (1) Slime or biomass accumulation in stagnant areas of tubing or equipment; (2) Developing iron sulfide deposits in pipes and equipment; (3) Abnormal decline in water injection rates, increased pressure due to formation pores and/or tubing clogging; (4) Increased $\mathrm{H}_{2} \mathrm{~S}$ levels in wells and tanks; (5) Sharp increase in pitting type corrosion in tubing and equipment; (6) Changes in the classification of the oil and gas from fresh to sour, resulting in economic losses; (7) Viscosity instability or degradation of the gels of fracture during mechanic stimulation works; (8) Faster increase of water cut.

How to control bacteria. Bacteria are controlled by mechanical and operational measures, avoiding accumulation of solids, eliminating stagnant areas, removing solids from the system (routine pigging) and through chemical control with biocides (Cruz, et al., 2015).
Problems caused by Sulfate Reducing Bacteria (SRB) in crude oil production. Sulfate Reducing Bacteria (SRB) is a group of anaerobic microorganisms that generate a lot of problems in oil production. Not only produce corrosion damage also decrease the permeability of the fine pores of the reservoir rock, making it difficult, and sometimes even preventing, secondary oil recovery by water injection. They reduce the sulfate ion $\left(\mathrm{SO}_{4}^{2-}\right)$ to sulfur and hydrogen sulfide, which combines with $\mathrm{Fe}^{2+}$ ion to form iron sulfide (FeS), can grow in fresh or salt water, wastewater, soil and drilling or completion fluids of oil and gas wells. The optimum growth temperature of the SRB is between 25 and $37^{\circ} \mathrm{C}$ and a pH between 6 and 8. Once formed the biofilm, this becomes in a micro niche, oxygen concentration inside the biofilm is decreased due microbial metabolism, which promotes environmental conditions for bacterial growth of SRB. Among the main SRB there are:

a) Desulfovibriodesulfuricans,

b) Desulfonemalimicola,

c) Desulfobulbuspropionicus,

d) Desulfobacterpostgatei,

e) Desulfosarcinavariabilis,

f) Desulfomonasacetoxidans. 
Sulfate reduction by microorganisms is a complex process involving several reactions. Neverhtless, global reaction catalyzed by SRB is represented as follows:

$$
4 \mathrm{Fe}^{2+}+(\mathrm{SO})_{4}{ }^{=}+4 \mathrm{H}_{2} \mathrm{O} \rightarrow \mathrm{FeS}+3 \mathrm{Fe}(\mathrm{OH})_{2}+2 \mathrm{OH}^{-}
$$

Some wells do not exhibit high levels of $\mathrm{H}_{2} \mathrm{~S}$ although both high SRB and iron sulfide concentrations are found in them. This is because once $\mathrm{H}_{2} \mathrm{~S}$ is generated in the reservoir; it is carried to the aqueous phase and then sequestered by ferrous ions or dissolved in the residual oil phase. Low $\mathrm{H}_{2} \mathrm{~S}$ wells generally have high contents of iron from the formation, which increases corrosion. Minerals that can be considered capable to sequester $\mathrm{H}_{2} \mathrm{~S}$ are: siderite $\left(\mathrm{FeCO}_{3}\right)$, hematite $\left(\mathrm{Fe}_{2} \mathrm{O}_{3}\right)$ and magnetite $\left(\mathrm{Fe}_{3} \mathrm{O}_{4}\right)$. These minerals in contact with $\mathrm{H}_{2} \mathrm{~S}$ generate iron sulfides, especially Pyrrhotite (FeS) and pyrite $\left(\mathrm{FeS}_{2}\right)$.

Formation Damage due to Bacteria (FDB). The reservoirs are the only components of the water injection system cannot be changed during the life of the secondary recovery project. Inside tubings and surface facilities, injection water circulates but in reservoirs it accumulates (replacement of extracted oil), distributes (advancing of injected water) and possibly by sweeping deficiencies or simply volume distribution breaks into producing wells.

The reservoir is able to function as habitat for natural growth of bacteria before it enters with injection water. Extensive bacteriological studies of a sample taken at 1,500 m, showed SRB's ability to grow and survive in sedimentary environments. They could have been introduced in geologically recent times by moving groundwater or by its own motion (bacteria moves in stagnant water with proper motions at about 0.06 to 0.47 $\mathrm{cm} / \mathrm{h}$ ). That is, connate water has bacterial activity prior to drilling.

There is evidence that water-based muds and/or intervention fluids (completion, well control, stimulation, fracturing, etc.) are potential carriers of bacteria from the surface, which can contaminate the reservoirs. Shear stress or break stress required to release the binder of sessile bacteria increases with contact time, at pipeline level; so there is no impediment to the biomass growth within the framework of the reservoir where, flow and shear stresses are very low. Microbiological process, which contributes to the loss of injection, varies from well to well depending on the reservoir and water quality (nutrient availability).
It has been observed that the bacterial density in sandstone is around $10^{7}$ cells/gr of dry sand. The isolated bacteria have sizes varying between 0.5 and 5 microns in diameter and 6 microns in length in the case of bacilli, and have different degrees of aggregation. The sessile population adds its "exopolysaccharide" to form within the reservoir rock biofilms patches of about 150-micron with bacterial populations that can reach $5 \times 10^{7}$ cells per $\mathrm{cm}^{2}$.

There are also certain bacteria-rock preferences. Ghalambor observed affinity of the bacteria tested, for minerals such as olivine (iron and magnesium silicate compound) and calcite.

Analysis of the material that generates injectivity loss by clogging usually indicates varying proportions of corrosion products (oxide and sulfide), scales and biomass. In case of formation damage by bacteria (FDB) biomass usually constitutes about $50 \%$ of all material and inorganic sulfides, carbonates, oxides, etc., constitute the remaining 50\%. Figure 5 shows an example of BFD (photo by SEM technique). The paper SPE 27006 presents a case study of BFD (Hayatdavoudi \& Ghalambor, 1996).

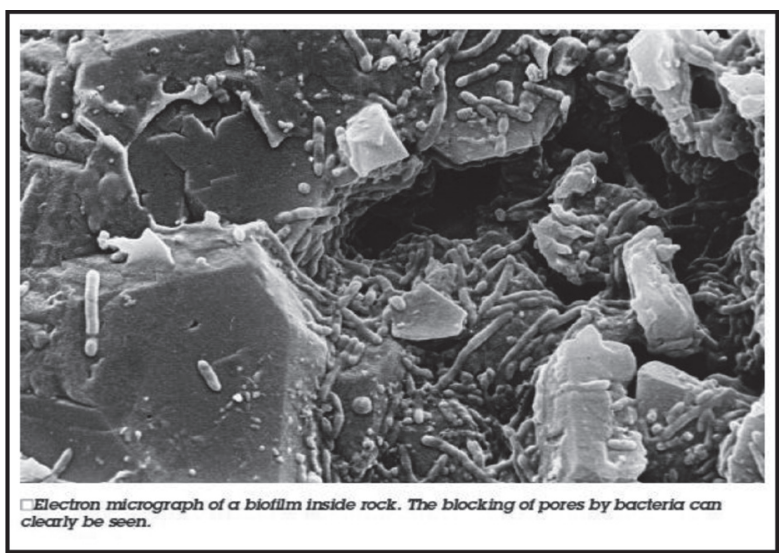

Figure 5. Bacterial Formation Damage

(Taken from Hayatdavoudi \& Ghalambor, 1996).

Use of biocides in stimulation treatment of producing wells. This methodology involves the injection into the pore matrix (Figure 6) of a train of stimulation fluids with a high concentration of biocide, 3 to 5 feet inside the formation, in order to remove damage caused by iron sulfide, reduce both microbiological contamination and production of hydrogen sulfide $\left(\mathrm{H}_{2} \mathrm{~S}\right)$, and lower levels of corrosion on the well casing and the entire production network (Rincón, et al., 2004). For detailed analysis of this 
issue, it can reviewed SPE 169449 paper. In this document is presented a methodology in the laboratory and at field scale for the characterization, selection and evaluation of stimulation fluids based in biocides, focused on the control of H2S and corrosion (Rincón, et al., 2004) (Cepeda \& Ballesteros, 2008) (Meneses, et al., 2017) (Ramos \& Marin, 2018) (Portwod \& Romero, 2018). The selection of biocides must be very careful, because some are deactivated by the presence of $\mathrm{H}_{2} \mathrm{~s}$ (Williams \& McGinley, 2010) (Gil, et al., n.d) (León, et al., 2003) (Torrado, et al., 2008).

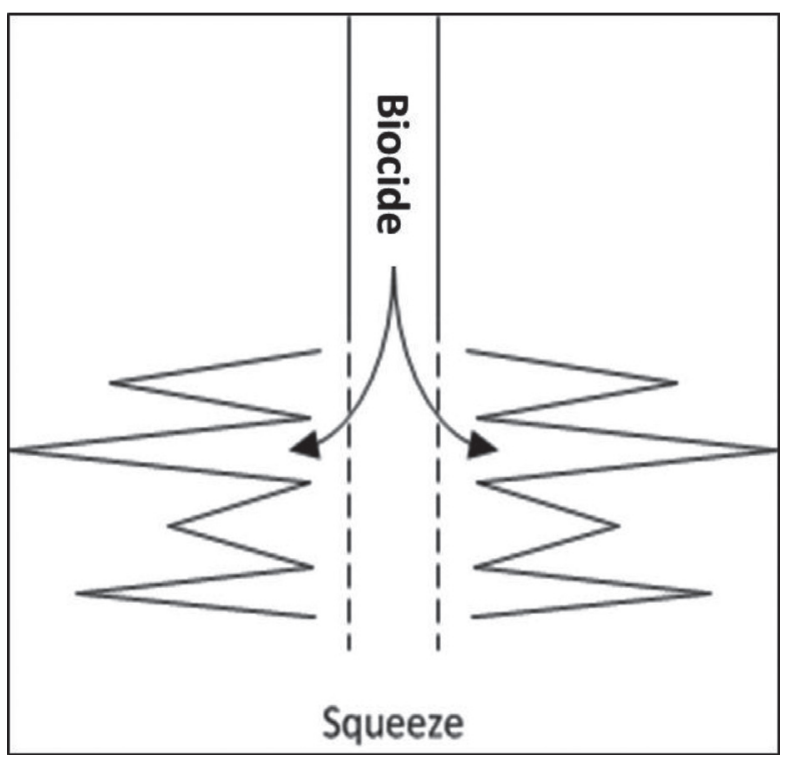

Figure 6. Biocide squeeze injection.

\section{Experimental methodology}

Microorganisms. Sulfate reducing bacteria (SRB) were isolated from injection and produced water from Chichimene Oil Field using Modified Starkey culture medium. Once were isolated in liquid medium, these SRB were cultivated at $50{ }^{\circ} \mathrm{C}$ and $\mathrm{pH} 7.2$ in Starkey Medium for $24-48 \mathrm{~h}$ and stored at $4{ }^{\circ} \mathrm{C}$.

Determination of Most Probable Number (MPN) of cells. Cultivable sulfate reducing bacteria were grown at $55{ }^{\circ} \mathrm{C}$ in Postgate $\mathrm{C}$ Culture medium (See Table 3) under anaerobic conditions $\left(\mathrm{N}_{2}^{\circ}\right.$ atmosphere $)$. For determination of number of cells per $\mathrm{mL}$, serial dilutions were carried out, taking $1 \mathrm{~mL}$ of cells and $9 \mathrm{~mL}$ od Postgate $\mathrm{C}$ medium, determining bacterial cells as most probable number (MPN) at the respective dilution at 14 and 28 days (León, et al., 2003).
Table 3. Composition of Modified Postgate C Culture Medium.

\begin{tabular}{|c|c|}
\hline Component & Amount \\
\hline $\mathrm{KH}_{2} \mathrm{PO}_{4}$ & $0.5 \mathrm{~g}$ \\
\hline $\mathrm{NH}_{4} \mathrm{Cl}$ & $1 \mathrm{~g}$ \\
\hline $\mathrm{Na}_{2} \mathrm{SO}_{4}$ & $4.5 \mathrm{~g}$ \\
\hline $\mathrm{CaCl}_{2} \times 2 \mathrm{H}_{2} \mathrm{O}$ & $0.06 \mathrm{~g}$ \\
\hline $\mathrm{MgSO}_{4} \times 7 \mathrm{H}_{2} \mathrm{O}$ & $0.06 \mathrm{~g}$ \\
\hline Sodium Lactate & $10 \mathrm{~mL}$ \\
\hline Yeast Extract & $1 \mathrm{~g}$ \\
\hline $\mathrm{FeSO}_{4} \times 7 \mathrm{H}_{2} 0$ & $0.3 \mathrm{~g}$ \\
\hline Producing Wate & $1000 \mathrm{~mL}$ \\
\hline
\end{tabular}

Biofilm formation assays. Sand samples from Chichimene were physically milled in a mortar. One gram of sands from formation K2 Chichimene was added to a sealed assay tube supplemented with Starkey (See Table 4) and/or Postgate culture medium (See Table 3). Subsequently, these were sterilized at $121{ }^{\circ} \mathrm{C}$ during 15 $\mathrm{min}$. Five different assays were performed under different conditions in order to evaluate biofilm formation on the sands under anaerobic conditions at $55^{\circ} \mathrm{C}$.

Table 4. Composition of Modified Starkey Culture Medium.

\begin{tabular}{|c|c|}
\hline Component & Amount \\
\hline $\mathrm{KH}_{2} \mathrm{PO}_{4}$ & $0.56 \mathrm{~g}$ \\
\hline $\mathrm{NH}_{4} \mathrm{Cl}$ & $1.1 \mathrm{~g}$ \\
\hline $\mathrm{Na}_{2} \mathrm{SO}_{4}$ & $0.56 \mathrm{~g}$ \\
\hline $\mathrm{CaCl}_{2} \times 2 \mathrm{H}_{2} \mathrm{O}$ & $0.12 \mathrm{~g}$ \\
\hline $\mathrm{MgSO}_{4} \times 7 \mathrm{H}_{2} \mathrm{O}$ & $2.2 \mathrm{~g}$ \\
\hline Sodium Lactate & $3.8 \mathrm{~mL}$ \\
\hline Yeast Extract & $0.5 \mathrm{~g}$ \\
\hline Producing water & $1000 \mathrm{~mL}$ \\
\hline
\end{tabular}

Every sample was inoculated with a pool of SRB isolated from Chichimene. Microorganisms were cultured by 4 weeks, in order to get cell immobilization onto sand grains and give time for biofilm formation. In Table 5 is displayed growth assays designed for validation of biofilm formation.

Coreflooding Tests. Coreflooding tests were carried out in displacement equipment under the following operation conditions (See Figure 7): 3000 psi of confining, $500 \mathrm{psi}$ of $\mathrm{BP}$ and $100^{\circ} \mathrm{F}$. 
Table 5. Experiments of growth and biofilm formation with Chichimene sands.

\begin{tabular}{|c|c|c|}
\hline Experiment & Culture Medium & Addition of SRB pool \\
\hline BF-1 & Only Injection Water & NO \\
\hline BF-2 & $\begin{array}{c}\text { Injection Water + Starkey } \\
\text { 1X Medium }\end{array}$ & NO \\
\hline BF-3 & $\begin{array}{c}\text { BSR Pool + Injection } \\
\text { Water + Starkey 1X } \\
\text { Medium }\end{array}$ \\
\hline BF-4 & $\begin{array}{c}\text { Injection Water + } \\
\text { Postgate 1X Medium }\end{array}$ & NO \\
\hline BF-5 & $\begin{array}{c}\text { BSR Pool + Injection } \\
\text { Waster + Postgate 1X } \\
\text { Medium }\end{array}$ & YES \\
\hline
\end{tabular}

Note: All microbial cultures were carried out at $\mathrm{pH} 7.0$ and $55^{\circ} \mathrm{C}$.

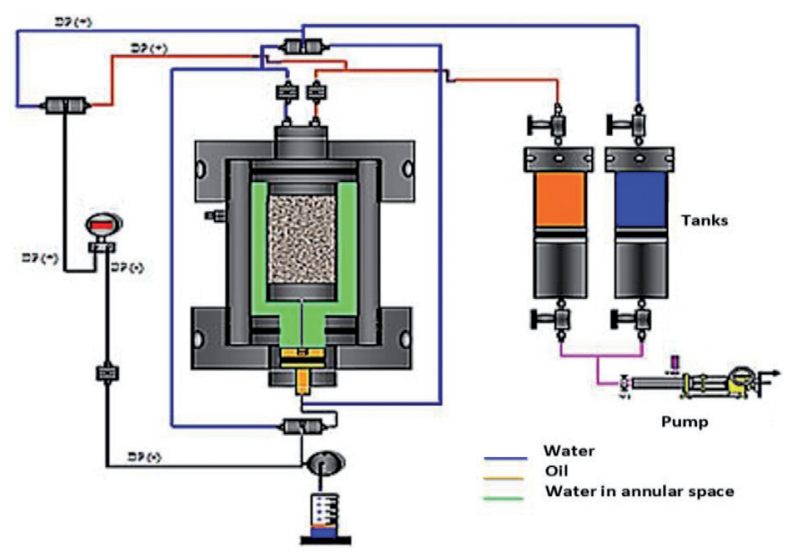

Figure 7. Coreflooding Equipment

Bacterial cells $\left(10^{6}\right.$ cells $\left./ \mathrm{ml}\right)$ cultured in a modified Starkey culture medium. The evaluation protocol was the following:

- Determination of absolute permeability (k) at environmental Temperature in production mode: Injection Flow of $1 \%(w / v) ~ K C l$ until stationary condition at $1 \mathrm{cc} / \mathrm{min}$.

- Thermal expansion and determination of absolute permeability (k) at $100^{\circ} \mathrm{F}$.

- Determination of baseline: Displace in production mode 10 pore volumes of sterilized Starkey medium without bacteria filtered in 0.45 micrometer filter until stationary conditions $(\Delta \mathrm{k}<10 \%$ in the range of measurement). Injection at 1,2 y $3 \mathrm{cc} / \mathrm{min}$ and correction of permeability using Darcy Model.

- Inoculation of microorganisms in the porous core. In injection mode displace 15 porous volumes of sterilized Starkey medium inoculated with SRB pool from Chichimene in stages of $30 \mathrm{~min}$ of injection and close the system by $15 \mathrm{~min}$ for a total of 5 injections of 3 porous volumes. Injection flow was set at $1 \mathrm{cc} / \mathrm{min}$ under stirring.
- Samples were collected at different times and numbers of SRB were determined as described previously.

- The system was closed by $24 \mathrm{~h}$, and after this, the displacement was started in production mode adding 6 porous volumes of Starkey medium. This stage was carried out by 10 days with injection flows of $0.5,1$ and $1.5 \mathrm{cc} / \mathrm{min}$.

- A return $\mathrm{k}$ was measured every day (in production mode) at the same injection flows $(0.5,1$ and $1.5 \mathrm{~mL} /$ $\mathrm{min}$ ) and compared with the baseline, and therefore, we determined the variation of $k$ in function of time. Subsequently, displacement with at least 10 porous volumes was carried out until stationary stage. Permeability was corrected using Darcy model.

- Finally, samples from return were analyzed for determination of number of cells per $\mathrm{mL}$ as described above.

\section{Results and discussion}

Biofilm cultures on Chichimene Sands. Biofilm formation was detected in the different conditions of culture using sand grains from Chichimene formation (See Table 6). Moreover, during a period of 4 weeks, not only we observed cell growth on the sand grains, if not a $\mathrm{H}_{2} \mathrm{~S}$ production was detected (data not shown), which is demonstrating bacterial growth of viable cells in injection waters at the used environmental conditions $\left(55^{\circ} \mathrm{C}\right.$ y pH 7). On the other hand, higher SRBs concentrations in biofilm experiments were found in samples with Starkey medium. However, samples with only injection waters were able to form biofilm in the sand grains.

Table 6. Experiments of cell growth and biofilm formation in sand grains from formation of Chichimene Oil-Field.

\begin{tabular}{|c|c|c|}
\hline Experiment & Culture medium & $\begin{array}{c}\text { Biofilm } \\
\left(\mathbf{N}^{\circ} \text { Cells/gram of }\right. \\
\text { sand })\end{array}$ \\
\hline $\mathrm{BF}-1$ & Injection Water & $1.48 \times 10^{3}$ \\
\hline $\mathrm{BF}-2$ & $\begin{array}{c}\text { Injection Water + Starkey } \\
\text { Medium 1X }\end{array}$ & $1.34 \times 10^{4}$ \\
\hline $\mathrm{BF}-3$ & $\begin{array}{c}\text { SRB pool + Injection Water + } \\
\text { Starkey 1X Medium }\end{array}$ & $9.50 \times 10^{4}$ \\
\hline $\mathrm{BF}-4$ & $\begin{array}{c}\text { Injection Water + Postgate 1X } \\
\text { Medium }\end{array}$ & $6.90 \times 10^{4}$ \\
\hline $\mathrm{BF}-5$ & $\begin{array}{c}\text { SRB pool + Injection Water }+ \\
\text { Postgate 1X Medium }\end{array}$ & $5.71 \times 10^{4}$ \\
\hline
\end{tabular}

Coreflooding Test. In Table 7 are shown results of determination of $\mathrm{K}$ under return mode in order to determine formation damage caused by bacteria (biofilm formation). In the Figure 8 are displayed the main results obtained in this test with the proposed methodology. 
Table 7. Permeabilities during coreflloding test under biofilm formation conditions.

\begin{tabular}{|c|c|c|}
\hline Variable & $\begin{array}{c}\text { Permeability } \\
(\mathbf{m D})\end{array}$ & $\begin{array}{c}\text { Reduction of } \\
\text { Permeability } \\
(\%)\end{array}$ \\
\hline $\begin{array}{c}\text { Absolutek at environmental } \\
\text { temperature (KCl 1\%) }\end{array}$ & $458 \mathrm{mD}$ & - \\
\hline $\begin{array}{c}\text { Initial k with Starkey } \\
\text { Medium }\end{array}$ & $373 \mathrm{mD}$ & $76.76 \%$ \\
\hline $\begin{array}{c}\text { Return k with Starkey } \\
\text { Medium-Day 1 }\end{array}$ & $86.67 \mathrm{mD}$ & $80.69 \%$ \\
\hline $\begin{array}{c}\text { Return k with Starkey } \\
\text { Medium-Day 2 }\end{array}$ & $72.0 \mathrm{mD}$ & $92.97 \%$ \\
\hline $\begin{array}{c}\text { Return k with Starkey } \\
\text { Medium-Day 3 }\end{array}$ & $26.20 \mathrm{mD}$ & $93.54 \%$ \\
\hline $\begin{array}{c}\text { Return k with Starkey } \\
\text { Medium-Day 4 }\end{array}$ & $24.09 \mathrm{mD}$ & $95.53 \%$ \\
\hline $\begin{array}{c}\text { Return k with Starkey } \\
\text { Medium-Day 5 }\end{array}$ & $16.66 \mathrm{mD}$ & \\
\hline \multicolumn{2}{|c|}{} \\
\hline
\end{tabular}

In Figure $\mathbf{8}$ is shown results obtained during coreflooding assay. It can be observed the displacement of 10 pore volumes of $1 \%(\mathrm{w} / \mathrm{v}) \mathrm{KCl}$ for determining absolute $\mathrm{k}$. Then, 20 pore volumes of culture medium (Starkey medium) were injected at flows of 1,2 and $3 \mathrm{cc} / \mathrm{min}$. Subsequently, 15 pore volumes of bacterial cells were injected at $1 \mathrm{cc} / \mathrm{min}$. In the whole process flows did not overcome $1.2 \mathrm{psi}$. Once SRB were injected, the system was closed by $24 \mathrm{~h}$, and everyday were displaced 10 pore volumes without bacteria in order to measure permeability return. Maximum pressure differentials were reached at the fifth day of evaluation with 1.5 psi. Once the coreflooding was finished, the plug was cut and treated with glutaraldehyde for cell fixation (TM0194 - Nace Internacional, 2014), (Golding, et al., 2016) in order to observe them by SEM. In Figure 9a, 9b and $9 \mathrm{c}$ are depicted inlet, medium and outlet zones, respectively.

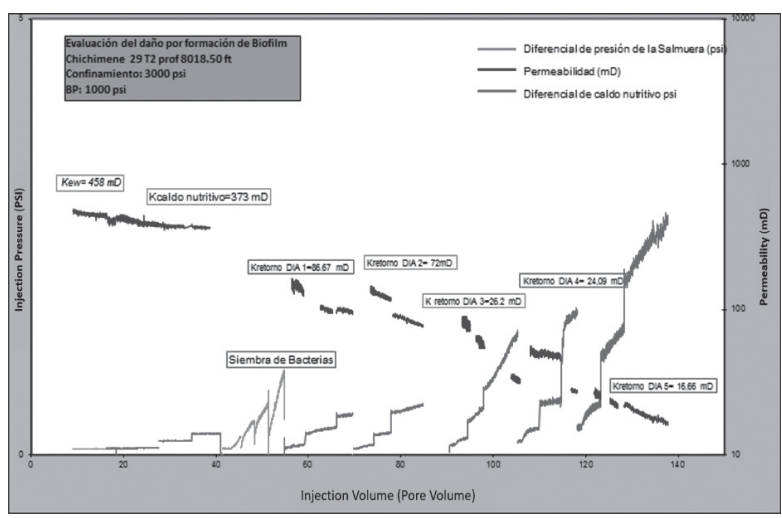

Figure 8. Evaluation of formation damage caused by bioaugmentation and Return of Permeability during coreflooding with injection of SRB cells.
In Figures 9 and $\mathbf{1 0}$ is observed presence of bacteria with size around 1 micron. Biofilm formation can be visualized in SEM pictures from Figure $\mathbf{9 b}$ and an important association of bacteria can be observed in Figure 9c. These analyses confirm presence of bacteria adhered to the sand grains. Additionally, samples of these grains were withdrawn and re-inoculated in order to determine cell viability. Cells isolated from these grains grown in a Postgate $\mathrm{C}$ medium and Starkey medium in the range of $10^{2}-10^{3}$ cells $/ \mathrm{mL}$, which demonstrates that this cells can form biofilm in the grains.

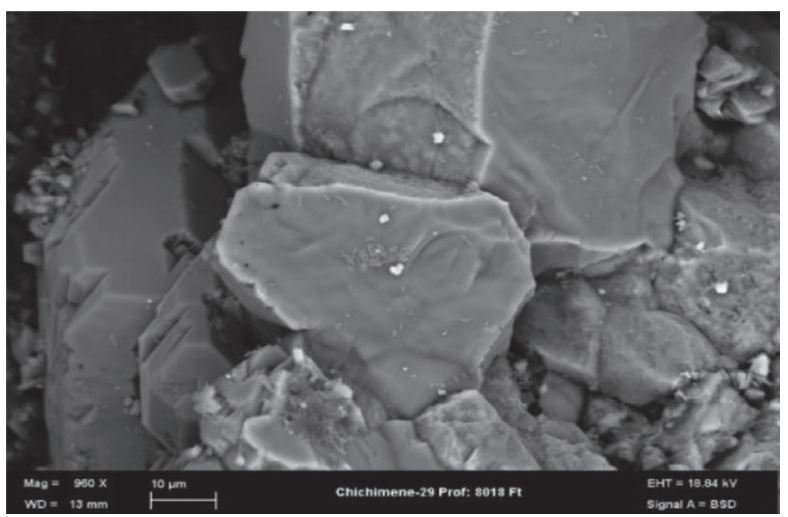

Figure 9a. SEM picture of plug inlet face.

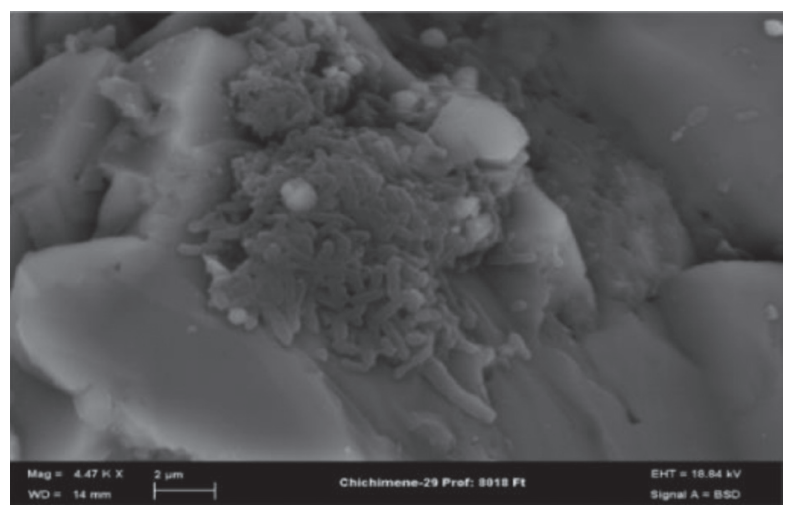

Figure 9b. SEM picture of bacterial biofilm.

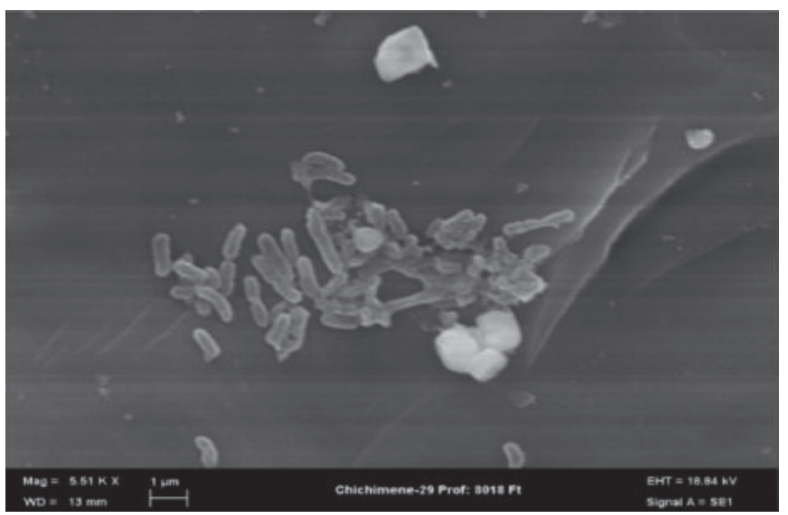

Figure 9c. SEM picture of an Accumulation of bacteria. 


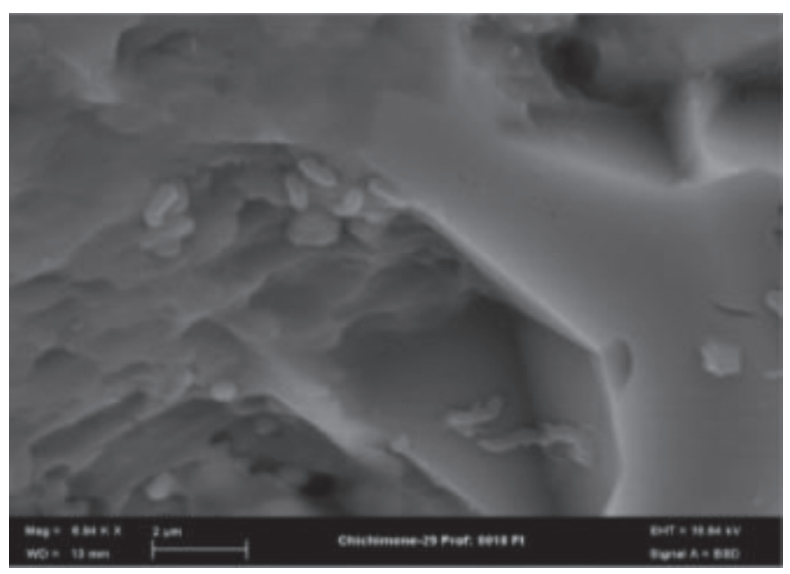

(A)

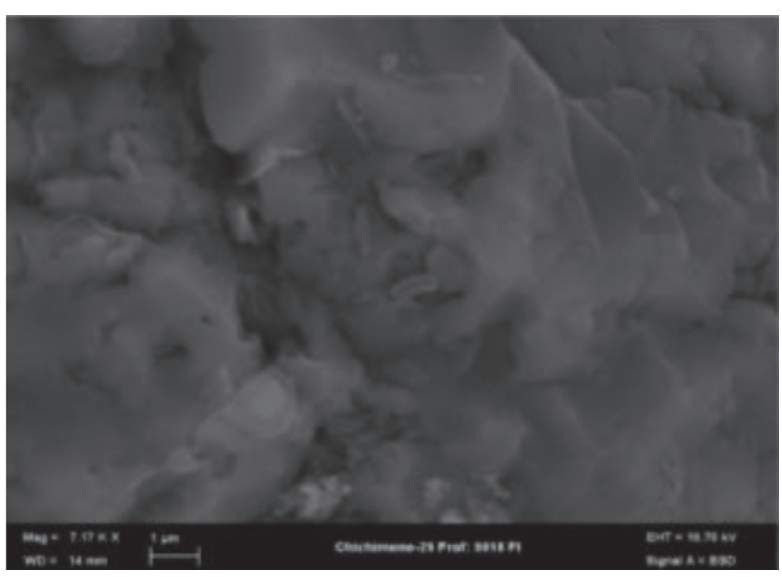

(B)

Figure 10. Morphology of bacterial Biofilm in the middle zone of the plug.

In addition, the central zone of biofilm of the plug, bacteria are also adhered in the sand grains. Bacterial cells were also visualized in this zone of the plug. In this sense, presence of bacteria associated to sand grains with the correspondent progressive increment in the pressure differences during measurements of return permeability can be attributed to damages caused by bacteria.

\section{Conclusions}

- In this study, a lab protocol for evaluation of formation damage caused by bacteria from injection water was developed.

- The results showed that throats from the plug were occluded by biofilm under lab conditions.

- SBR can survive, proliferate and be active under reservoir conditions. Thus, bacteria can damage the reservoir by biomass formation and sulfide hydrogen.

\section{Recommendations}

- To evaluate different types of stimulation treatments with biocides in order to remove formation damage in the reservoir by both biofilm and sulfide hydrogen.

\section{Acknowledgements}

The authors acknowledge the Colombian Institute of Petroleum, ICP, for allowing the publication of these results. This study is part of the Agreement EcopetrolUIS. Financial support from Ecopetrol-ICP is gratefully acknowledged.

\section{References}

1. Biocide Stimulation in Oil wells for Down Hole Corrosion Control and Increasing Production. Pedro R. Rincón, Benton Vinccler C.A, John P. McKee, SPE, Benton Vinccler C.A, Carola E. Tarazón, Benton Vinccler C.A., Luis A. Guevara, Benton Vinccler C.A. SPE 87562.

2. Berlanga, $M$ and Guerrero, R. 2016. Living together in biofilms: the microbial cell factory and its biotechnological implications. Microb Cell Fact, 15, 165.

3. Cepeda, S. N. R., \& Ballesteros, D. Y. P. (2008). Evaluación de la velocidad de corrosión de un acero aisi-sae 1020 en un sistema multifásico nacl 3\%-aceite mineral-co2-h2s por medio de un simulador de flujo. Fuentes: El reventón energético, 6(2), 2.

4. Cruz, H. D. O., Duque, J. P. V., \& Marulanda, J. F. F. (2015). Propuesta metodológica para el control y monitoreo de un proceso de inyección de agua. Revista Fuentes, 13(2).

5. Díaz, R. J., Navarro, S. F. M., \& Tavera, C. P. S. (2007). Modelo estadístico para la realización de analogías orientadas a procesos de recobro mejorado. Revista Fuentes, 5(1).

6. E., Summer, S. Duggleby, C. Janes and M. Liu. 2014. Microbial populations in the O\&G: Application of the knowledge. Paper no. 4376. Proc. CORROSION 2014 (San Antonio, TX: NACE International 2014).

7. Evaluation of biocides used form control of SRB present in oilfield water plant. Orletta R. Leon, Universidad de Zulia Venezuela. 
8. Evaluation of biocide used in the oil industry before the Phenomenon of Corrosion Induced by Sulfate Reducing Bacteria. Y. Gil Figueroa, G. Lopez Gomez, Y. Bruzual, C. Rodriguez, D. Guevara, N. Bravo, J. L. Prin. Department of Materials Science. Corrosion Laboratory. Institute for Research in Biomedicine and Applied Sciences. Dr. Susan Tai. (IIBCA), Universidad de Oriente. Venezuela. School of Engineering and Applied Sciences. Department of Mechanical. Universidad de Oriente. Venezuela

9. Galvis, F. W. L., Suarez, C. E. N., \& Navarro, S. F. M. (2013). Simulación de un proceso de inyección de agua en un modelo físico escalado $3 \mathrm{~d}$. Revista Fuentes, 11(2).

10. Ghalambor, A., Hayatdavoudi, A., \& Shahidi-Asl, M. (1996). A Study of Formation Damage of Selective Mineralogy Due to Bacterial Plugging. SPE Advanced Technology Series, 4(01), 118-127.

11. Golding, C. G., Lamboo, L. L., Beniac, D. R., \& Booth, T. F. (2016). The scanning electron microscope in microbiology and diagnosis of infectious disease. Scientific reports, 6, 26516.

12. Impact of Desulfovibrio alaskensis biofilms on corrosion behavior of carbon steel in marine environment. A.J. Wikiel, I. Datsenko, M. Vera and W. Sand. 2014. Bioelectrochemistry, 97, 52-60.

13. León, O., Cárdenas, C., Araujo, I., \& Carruyo, J. (2003). Evaluation of biocides used for control of SRB presents in a oilfield water plant. Revista Técnica de la Facultad de Ingeniería. Universidad del Zulia, 26(1).

14. Lomans, B.P.; de Paula, R.; Geissler, B.; Kuijvenhoven, C.A.T.; Tsesmetzis, N., 2016. Proposal of Improved Biomonitoring Standard for Purpose of Microbiologically Influenced Corrosion Risk Assessment. SPE International Oilfield Corrosion Conference and Exhibition, 9-10 May, Aberdeen, Scotland, UK. SPE179919-MS.

15. M.G. Jaimes, A. Villar, M.A. Escobar, Ecopetrol S.A; and N.P. Acevedo, Natfrac Corporation SPE 169449. Conceptual Study and Experimental Protocol for The Selection and Evaluation of Matrix Stimulation Treatments with Biocides, focused on $\mathrm{H}_{2} \mathrm{~S}$ and Corrosion Control in Producer Wells of Fields Undergoing Secondary Recovery.

16. Martin, C. A. G., \& Páez, E. M. (2017). Efeito da salinidade na tensão interfacial do sistema óleo/ agua em condições isobáricas e incremento gradual da temperatura. Revista Fuentes, $15(2), 117-124$.

17. Maya, G. A., Herrera, J. J., Orrego, J. A., Rojas, F. A., Rueda, M. F., \& Manrique, E. J. (2018). Effect of ionic composition in water: oil interactions in adjusted brine chemistry waterflooding: preliminary results. Revista Fuentes, 16(2).

18. Meneses, A. F. O., Moreno, L. F. C., \& Plata, J. A. R. (2017). Metodología experimental para la estimación de permeabilidades relativas en dos y tres fases por medio de ajuste histórico. Revista Fuentes, 15(1), 75-85.

19. Oilfield Review. Microbes Oilfield Enemies or Allies. Summer 2012

20. Portwood, J. T., \& Romero, J. L. (2018). Waterflood Conformance Improvement-Practical Considerations \& Lessons Learned. Revista Fuentes, 16(2).

21. Prokaryotes: the unseen majority. W.B. Whitman, D.C. Coleman and W.J. Wiebe. 1998. Proc Natl Acad Sci USA, 95(12), 6578-6583.

22. Ramos, L., \& Marin, A. (2018). Evaluación y experiencias en el control de conificación en pozos con alto corte de agua en yacimientos con empuje hidráulico. Revista Fuentes, 16(2).

23. TM0194-2014, 2014. Field monitoring of bacterial growth in oil and gas systems. NACE International, item no. 21224.

24. Torrado, J. R., Calixto, D. G., Sarmiento, A. C., \& Panqueva, J. A. (2008). Evaluation of molybdate and nitrate on sulphate-reducing bacteria related to corrosion processes in industrial systems. Revista Argentina de microbiologia, 40(1), 52-62.

25. Velandia, J. L. P. (2013). Simulación numérica del flujo bifásico agua-petróleo en un medio poroso. Fuentes: El reventón energético, 11(2), 10.

26. Williams, T. M., \& McGinley, H. R. (2010, January). Deactivation of industrial water treatment biocides. In CORROSION 2010. NACE International.

Recepción: 20 de septiembre de 2018

Aceptación: 26 de agosto de 2019 